\title{
Scientific Article Education Evaluation Of Inclusion Of Junior High Schools In Central Java
}

\author{
Eka Sari Setianingsih ${ }^{\mathrm{a}}$, Ari Widyaningruma \\ a Semarang PGRI University, Faculty of Education, Semarang, Indonesia
}

Corresponding e-mail: ekasari129@yahoo.com

\begin{abstract}
Education inclusion is schools had to accommodate all children without looking at the physical condition, intellectual, social emotional, linguistic or other conditions. Education inclusion is a education services to its students have needs special education in regular school which is extraordinarily good in the sense disorder, sluggish learning. The study is done for the purpose evaluate education inclusion junior high schools in central java. The study is done by using the method qualitative is descriptive analytical. As for that became a source primary data in this research is a head of school, teachers guidance and counseling, class teachers and friends students children with special needs. Technique data collection used is interview, FGD and questionnaire. The outcome of the findings show the implementation of inclusions in education of SMP N 4 Mojosongo and SMP N 20 Surakarta had already taken the process of identification and assessment for each student received, while in SMP N Hasanuddin 10 Semarang not yet. The implementation of inclusive education meet various obstacles which are often reported was a mistake an understanding of the concept of inclusion of education, any regulation or policy that has not been consistent, a misconception perception teachers think of children with special needs. As for assessment an activity to evaluate learning is considered inferior namely shows that teachers were having difficulty in provide an assessment to crew members because the absence of guidance and guidelines raw, in addition there has been no unified perceptions teachers at schools of the existence of children with special needs and lack of GPK. The conclusion is there needs to be review of and a review on the implementation of administration and evaluation good accepting new students and awareness all parties to actively involved in various activities to support the implementation of education inclusion, teachers at school of inclusion of prosecuted do collaboration with a profession or resources another in planning, the implementation and evaluation.
\end{abstract}

Keywords: $\quad$ evaluation, education inclusion, children with special needs (abk), smp

\section{INTRODUCTION}

The implementation of education inclusion guaranteed and arranged in The minister of national education number 70 years 2009. Therefore, the state of having an obligation to providing quality education services to all its citizens without exception including those that have differences in the ability

Be proof that is visible is that even though children with special needs had participated in the education in accordance with the level of education formal existing but when crew members back into the environment behold, there are still various refusal for children with special needs to be favorably received as a member of other public.

Along with the social life, there was a view that children with special regarded as the figure of individuals useless, necessary exiled.
But, with the advent of human civilization, will begin different view. They started valued and have a common right like a normal other. Children with special needs get the same opportunity with children other normal in education, only be true if considered from the point of view of education, because of its characteristics different with the son of a normal causing in the process of education they need service approach and distinct method with for a special approach.

School (inclusion in Indonesia) is a regular school which accommodates all students the normal good and the with special needs disabled athletes (disabed, intellectual, social, emotional, mental, smart, talented special remote areas/underdeveloped, the estranged, natural disasters/social disaster/poor), a distinction rank, skin color, gender, nations, race, language, culture, religion, residence, political group, twins, orphans, orphaned, the rural, towns, waif, homeless, a wasted, the involved in juvenile 
court system, children exposed to the conflict zones weapons, the beggars, children affected narcotics hiv / aids (ODHA ), the nomadic, etc according to the ability and needs.

School for children with special needs one of them is to follow the segregation model that is put children with special needs in schools special or outside regular school, them apart from friends. Special school it has curriculum, facilities learning and special teachers, so that they not be allowed develop the potential optimally.

Through education inclusion, difersitas character, and skill school tuition diakomodir in a sage manner, namely by provided room to all to learn .Even, in education inclusion, the difference is considered as a source of learning, rather than as a matter of [1]. In addition, one international agreements that drives formation of education system is conventional inclusion on the right of person with disabiliteis and an optional protocol passed in march 2007. Article 24 of this convention mention that every country are obliged to hold education system inclusions in all educational levels. One it is intended is to drive achieve full participation children with special needs in society.

In the minister of national education number 70 years 2009 about education inclusion for students had a and have the potential intelligence and/or talent privilege of being formal rules umbrella the effort to education inclusion in indonesia. The minister the load with complete the guidelines about education of inclusion of starting from planning to the implementation. In addition, the minister is also require local government districts pointed at least one school that must be held education inclusion. So also, circulars director general higher mone no. 380 / c.66 / mn / 2003, 20 january 2003 concerning education inclusion that in every of all districts throughout indonesia sekurang lack of there must be 4 school held of inclusion of which was in the primary level, junior high school, vocational high schools each at least one school.

Both of education and evaluation inclusive it is not easy .Because it involves many parties and many kompenen mutual sustainable, so until now the education system inclusive could not go quite as expected by all parties. Especially at a school that runs education inclusion but does not have a decree (SK) appointment of the education system inclusion better than the head of the region or head of local education

The implementation of the evaluation of education inclusion has not in accordance with the existing mechanism .So that the handling of crew members to the students also did not yet maximize and running what the presence of . For that this problem be essential to review deeply in research titled, "EDUCATION EVALUATION OF INCLUSION OF JUNIOR HIGH SCHOOLS IN CENTRAL JAVA".

\section{RESEARCH METHODS}

This research was done using the method qualitative is descriptive analytical. As for that became a source primary data in this research is a head of schoool, teachers guidance and counseling, class teachers and friends students children with special needs. Technique data collection used is interview, observation, FGD, and quetioner. Analysis data using stage the qualitative study. While in check data validity using a technique triangulation data .

\section{RESULTS AND DISCUSSION}

Education is a system of inclusion of education services that require children with special needs disabled athletes study in nearest school in an ordinary classroom wth they friends in the same age. School education providers inclusion a school accommodate all students in the same school. The scope of the concept of children with special needs (ABK) can be described as into two groups great children with special needs (ABK) temporary and children with special needs (ABK) that settled (permanent) .

As for who is a source of primary data in this research is a head of school, the tutor/counseling teacher, grade teachers, the parents of students, regular students (normal), department of education officers district and provincial related. While secondary data sources in this research obtained by means the study of literature available, namely by reading literature and the documents in schools and other places that are related to the, looking at the regulation as well as the legislation relating to a focus research namely the implementation of inclusions in education schools .

SMP Negeri 20 Surakarta Is junior high school new unit standing with the decision of education and culture minister of the republic of indonesia no. $0299 / 0 / 1982$, established on land with broad 11320 square meters located in urban village jagalan kecamatan jebres city surakarta, on the 22nd december 1982.

In a lesson 2008/2009 SMP N 20 Surakarta designated as a candidate school national standards by developing 8 national education standards, belong to develop school with empowerment activities the school. This is done to accommodate children with sepacial needs which incidentally from year to year there always. According to a statement the school principal seem that the SMP N 20 
Surakarta are already proficient importance to education for all for students good students normal and with special needs. Through education inclusion, difersitas character, and skill first students in a sage manner, to make room for all to learn. Even, in education inclusion, the difference is seen as a source of learning, rather than as a matter

In SMP N 20 Surakarta there are several the children with special needs, of them is in category slowleaner (sluggish study) and blind people. But based on the data from a pitch that in SMP N 20 Surakarta dominant there are many children category of sluggish learning (slowlearner). The following data of children with special needs and types of disabilities in SMP N 20 Surakarta that is:

\begin{tabular}{|c|c|c|c|c|c|}
\hline No & Sekolah & Alamat & Siswa & Kls & $\begin{array}{l}\text { Jenis } \\
\text { Ktunaan }\end{array}$ \\
\hline 1 & \multirow{6}{*}{$\begin{array}{l}\text { SMP N } 20 \\
\text { Surakarta }\end{array}$} & \multirow{6}{*}{$\begin{array}{l}\text { Jl. Surya no. } \\
155 \text { jagalan } \\
\text { jebres } \\
\text { surakarta }\end{array}$} & $\begin{array}{l}\text { MF } \\
\mathrm{K} \\
\end{array}$ & $\begin{array}{l}\text { VIII } \\
\text { / A }\end{array}$ & $\begin{array}{l}\text { Lamban } \\
\text { Belajar }\end{array}$ \\
\hline 2 & & & MJ & $\begin{array}{l}\mathrm{VIII} \\
/ \mathrm{B} \\
\end{array}$ & $\begin{array}{l}\text { Lamban } \\
\text { Belajar }\end{array}$ \\
\hline 3 & & & WAS & $\begin{array}{l}\mathrm{VIII} \\
/ \mathrm{G} \\
\end{array}$ & $\begin{array}{l}\text { Lamban } \\
\text { Belajar }\end{array}$ \\
\hline 4 & & & RDM & $\begin{array}{l}\text { VIII } \\
/ \mathrm{D}\end{array}$ & $\begin{array}{l}\text { Lamban } \\
\text { Belajar }\end{array}$ \\
\hline 5 & & & $\begin{array}{ll} & \mathrm{M} \\
\mathrm{AE} & \\
& \mathrm{P} \\
\end{array}$ & $\begin{array}{l}\text { IX / } \\
\text { F }\end{array}$ & $\begin{array}{l}\text { Tuna } \\
\text { Netra }\end{array}$ \\
\hline 6 & & & $\begin{array}{l}\text { AS } \\
\mathrm{W}\end{array}$ & $\begin{array}{l}\text { IX / } \\
\text { D }\end{array}$ & $\begin{array}{l}\text { Lamban } \\
\text { Belajar }\end{array}$ \\
\hline
\end{tabular}

This is in accordance with the basic principle education inclusive compiled by the directorate school education remarkable (PSLB) the directorate general management of primary and secondary education mandikdasmen of the ministry of national education [2] that during allows, all children should be learn together without looking at difficulty or distinction of which there may be to them. Education inclusive is the education that the include all children in together in a climate and learning to the good quality education and suitable for the need individual students without differentiating children derived from the background, social conditions, economic ability, political, family, language, geographical (isolation place) to rest, sex, religion, and with the condition of physical or mental.

This research using analysis qualitative who describes and the handling data from each of the components evaluated covering components education of them are: (1) management student, (2) management curriculum, (3) management education workers, (4) management facilities and infrastructure, (5) financial management/funds, and
(6) management of the environment a school and society, and management specialized care [3].

Based on the results of research findings components input for participants students indicates that the process of accepting new students for children with special needs imposed equal to other children. As for the result of research findings in identifying children with special needs to the process accepting new students shows that SMP Hasanuddin 10 Semarang has not done the identification process and assessment to each student received in every the school tuition with the constraints of that SMP Hasanuddin 10 Semarang still within the transition period for the implementation of education inclusion, while in SMP N 4 Mojosongo and SMP N 20 Surakarta have done the identification process and assessment to each student received in every the school tuition in the new school year.

The outcome of the findings in school is not fully in accordance with criteria, whereas according to mone explicitly state that in order to identify children with special needs required knowledge of different types and level abnormality children of them are know abnormality physical, mental, intellectual, social and emotion [2]. Then to identify kind of abnormality children with special needs should not required equipment and knowledge specifically.

The outcome of the findings research against the type children with special needs exhibiting that kind of dissabilities that is known enough varied with the number of prosentase large were students sluggish learning (slowlearner). A kind of children with special needs at SMP Hasanuddin 10 Semarang there are three students to a category students the sluggish learning (slowlearner), the hearing impaired and physically handicapped. Then kind of dissabilities that is in SMP N 4 Mojosongo is the average sluggish learning (slowlearner), while in SMP N 20 Surakarta there are the student with categories sluggish learning (slowlearner) and blind.

Based on the results of the interview and observation information was obtained that the attitudes and behavior children with special needs having a positive attitude and cheerful, regular students or friends of children with special needs show a response positive that regular students receive the existence of children with special needs who are in a class to learn and play together regardless of their differences in status, social, economic and physical. Even in SMP Hasanuddin 10 Semarang teachers and regular students are very cooperative in help children with special needs that requires assistance without asked. Their attitude positif shown by regular students to children with special needs was a benchmark the success of the 
program inclusions in school, with a parallel and social justice.

Based on the outcome of the findings research on the curriculum in third research locations those in SMP N 4 Mojosongo Boyolali have used the combination and curriculum (KKM) different for children with special needs, while in SMP Hasanuddin 10 Semarang and SMP N 20 Surakarta shows that the curriculum used school is the regular curriculum (common) diduplikasikan or enforced as good for students normal (regular) or for children with special needs. This means that the curriculum imposed is regular curriculum same either at lesson plans, a syllabus, the purpose, the contents of/matter, the process as well evaluation all imposed same for all the students one thing that different is quantity at the time of the imposition of duties and test. Children with special needs get the number of problems that the more a bit as the test held .

These findings are considered to have already in accordance with the criteria of education programs inclusive and is supported mone that the curriculum used in the education system inclusive basically using the curriculum national standards same applies in public schools [4]. Then they also mentions duplicate means model curriculum develop and imposed curriculum to Children with special needs equally or similar (duplicate) with the curriculum used for students normal (regular) good on the objective, the matter, the process as well as in learning [4].

According to the research findings against the background of education and teacher employment status shows that teachers some people have scholar (S1) and those with civil servants. This shows that a professional teachers must have a background academic education in accordance with the demands law competence .

Related the findings from school, averages for each three schools that is SMP Hasanuddin 10 Semarang, SMP N 4 Mojosongo Boyolali and SMP N 20 Surakarta shows that education workers they meet the criteria special education and this according to the laws of teachers and lecturers in article 9 which states that educators (teachers) must have academic qualifications through graduates higher education or program scholar (act no 14 years 2005). But in three schools there has never been teacherchaperon specifically (GPK for Children with special needs). All related to Children with special needs handed over to teachers guidance and counseling .

The researchers found the fact that, in SMP N 4 Mojosongo there are three counseling teacher, but two of them is not majoring in an undergraduate degree of guidance and counseling but teachers parts of curriculum while others are education psychology. Similar case is in SMP Hasanuddin 10 Semarang, that at the school there are three counseling teacher but there was one teachers who have education are teachers english and be counseling teacher. This means that, human resources management that should be in school held education inclusion there are GPK but the fact counseling teacher existing alone its not based on criteria education as counseling teacher. This indicates that a professional teachers required to have a background academic education appropriate with competence the demands the act, but in fact not so.

Nevertheless, the schools were still try to fulfill and cover obstacles there those are by involving several teachers in the seminar, training and involved in MGBK to increase insight and science about children with special needs. Ideally the number of the tutor children with special needs must be in accordance with many crew members, but because the limited means, so school only incorporates class teachers who have followed training a manner of dealing with children with special needs as the tutor crew members in school. At a certain point if most urgent and is needed then the school will invite teachers slb to participate in guiding children with special needs.

Related the outcome of the findings research on public facilities school featured categories are sufficient and this meant that public facilities school is considered most of them are owned. The outcome of the findings are considered to have already in accordance with criteria the implementation of education inclusion although some public facilities was not owned by school, but the schools have consider wisely related placement for children with special needs in accordance with dissabilities placed on a class easily reached and not posing a children with special needs.

Based on the results of the findings from SMP N 20 Surakarta, SMP Hasanuddin 10 Semarang and SMP N 4 Mojosongo Boyolali several times get help and pay special attention of local government related the fulfillment of sarpras for Based on the results of the findings from SMP N 20 Surakarta, SMP Hasanuddin 10 Semarang and SMP N 4 Mojosongo Boyolali several times get help and pay special attention of local government related the fulfillment of sarpras for crew members. Assistance ever received by SMP N 4 Mojosongo among others was a sewing machine for children with special needs, leptop, printer but only in the first year the implementation of education of inclusion of just, then jammed. In SMP N 20 Surakarta own students children with special needs get government assistance of braile for students blind people without any funds of the community and for the business 
world. Assistance ever received by SMP N 4 Mojosongo among others was a sewing machine for children with special needs, leptop, printer but only in the first year the implementation of education of inclusion of just, then jammed. In SMP N 20 Surakarta own students crew members get government assistance of braile for students blind people without any funds of the community and for the business world.

In fact school have the limited time to fulfill infrastructure of the education system inclusion, including in sending the teachers to follow the training, seminars and workshop to assistance to child with special needs .

The activities for the assessment of learning which are not based on are considered to be among them were carry out a process of learning in the classroom is still in general there is no adjustment or adapted to reflect the needs and characteristics of the children with special needs, the implementation of a learning process given by a tutor class still likened to all students. This will be done by teachers because if the data teaching normal distinguished by children with special needs, then will spend time and it may be that other normal students will feel neglected that current children with special needs only adjust by a learning process that is.

The outcome of the findings is considered not fully in accordance with the implementation of education inclusive criteria, whereas according to mone that the implementation of learning activities on the model a certain class may be different to the implementation of the learning activities on class another (Depdiknas, 2007: 17). The outcome of the findings research through chief to assessment an activity to evaluate learning on the education inclusive show categories less than good. The outcome of the findings is considered its not based on criteria the implementation of education inclusive although there are still another aspect that having a conclusion low yield.

As for assessment an activity to evaluate learning having is considered inferior among them were on the implement evaluation learning to school tuition use the standard of graduation same. Special tools to child with special needs owned schools still very limited, while the school still use the standard of graduation as good for students normal as well as to child with special needs. This is done teachers to anticipate not passing class of child with special needs that will compete with students normal for join the national examination impose the standard of graduation same for all the students .

The outcome of the findings research on the difficulties encountered teachers in the aspect of planning of learning especially in preparing lesson plans shows that teachers were having difficulty in pour indicators to be used as material that should be adjusted to the ability of and characteristic of children with special needs. Similarly in preparing the matter and is planning to a source of learning shows that the teacher felt difficult because should be creating materials/matter dormitory in accordance with characteristic of children with special needs. Even some the school does not have planning terhdap children with special needs in other words all likened to normal other students.

As for the difficulties encountered teachers in the aspect of the implementation of the of learning especially in presenting / given the lectures and used media learning shows that the teacher felt difficulty because should give explanation and demos instrument/media repeatedly to crew members without the help of the existence of GPK. This condition caused besides instrument/medium used his condition is very limited is also due to teacher less used a media learning an interesting and in accordance characteristic child with special needs.

While the outcome of the findings research the difficulties encountered teachers in the aspect of evaluation of learning especially in the sight of study results show that teachers students had difficulty in provide an assessment to child with special needs because the absence of guidance and guidelines raw so that a judgment rendered teacher told child with special needs are in subjective .

The outcome of the findings relating to management of the environment, school was always involving parent of students in every learning, it means teachers time on communicate with parents of child with special needs, with the expectation that if interwoven cooperation between schools parents the process learning at home or in school to create a conducive and highly beneficial to the development of child with special needs because always be monitored, good at home or in school .

Special service given to child with special needs still in the form of counseling individual service, counseling services group and home visit. The rest if associated with therapy, all handed over to parents or every students in accordance with their dissabilities.

In spite of all weakness and obstacles faced by schools in the implementation of education inclusion, so large hope that schools stay revere the principle of inclusion of education that is there was no discrimination against students in a school. Actually every students has the same right to receive a quality education. All students have the ability to follow lessons for no see abnormality and their dissabilities. The difference is amplifier in improving the quality of learning for all students. Schools and teachers have ability to learn to respond to of the need for learning different. Education 
inclusion is ways to do education for all including child with special needs, where school of inclusion of provide an opportunity for child with special needs to seek the education with school age children at generally in one school .

Research on inclusion have are mostly done western countries in the $1980 \mathrm{~s}$, but research large scale pioneered by the national academy of sciences (the united states). The results show that classifications and the children disabled people in school, a class or place special are not effective and discriminatory. This service recommended that special education in segregatif only given limited based on the identification proper.

In accordance with The minister of national education of Indonesia number 70 years 2009 about education of inclusion of which states that the local governments district must pointed at least one school education perlevel that must be held education inclusions in each kecamatan. Thus clear that crew members also entitled to seek the education like school age children in general. But, education for children with special needs concerned with the results of after of education is not during the process education so that child with special needs have a decent life in the community. Strengthened will they be on article 2, education inclusive aimed to give more chance that as possible to all students had a physical, emotional, mental, and social or have the potential intelligence and or talent special to receive a quality education in accordance with their needs and capacities .

\section{SUMMARY}

Based on the research done and analysis of data so it can be concluded that:

In the implementation of the education program inclusion that desire children with special needs obtain education worthy still has not been felt. This is caused that children with special needs dispersed in remote areas of SLB so children with special needs have not been many are going to school and still many school held inclusion which has not yet registered in DIKSUS province of Central Java

To evaluate the performance of education inclusions in school there needs to be review of and a review on the implementation of administration and evaluation good accepting new students and awareness all parties to actively involved in various activities to support the implementation of education inclusions in the various components.

\section{REFERENCE}

[1] Sutrisno. 2012. "Signifikansi Pendidikan Inklusi dalam Mewujudkan Pendidikan untuk Semua". Mukaddimah, Vol. 18, No. 1, 2012, hlm. $31-40$.

[2] Direktorat Pendidikan Sekolah Luar Biasa (PSLB). 2007. Pedoman Umum Penyelenggaraan Pendidikan Inklusi. Jakarta: Direktorat Pendidikan Sekolah Luar Biasa (PSLB) Direktorat Jenderal Manajemen Pendidikan Dasar dan Menengah (Mandikdasmen) Kementrian Pendidikan Nasional (Kemendiknas).

[3] Direktorat Manajemen Pendidikan Dasar dan Menengah, Policy Brief, Sekolah Inklusi; Membangun Pendidikan Tanpa Diskriminasi, No. 9. Th.II/2008, Departemen Pendidikan Nasional

[4] Peraturan Menteri Pendidikan Nasional Nomor 70 Tahun 2009 Tentang Pendidikan Inklusi Bagi Peserta Didik yang Memiliki Kelainan dan Memiliki Potensi Kecerdasan dan/atau Bakat Istimewa. 